JIPS, Vol. 1 No. 1

Halaman: 29 - 36

Desember 2020
Jurnal Inovasi Pembelajaran di Sekolah

DOI: https://doi.org/10.51874/jips.v1i01.5

ISSN 2774-9363 (Cetak)

ISSN 2774-9746 (Online)
JIPS

Jurnal Inovasi Pembelajaran di Sekolah

\title{
Keefektifan Model Pembelajaran Think Pair Share Terhadap Sikap Belajar dan Hasil Belajar Siswa Pada Tema 2 Sub Tema 1 Sumber Energi Siswa Kelas IV SDN Kutosari Kabupaten Pekalongan
}

\author{
Muhammad Amirul Akrom Muttaqin ${ }^{1 *}$, Intan Rahmawati ${ }^{1}$, Ibnu Fatkhu Royana ${ }^{1}$ \\ ${ }^{1}$ Universitas PGRI Semarang \\ "Email: amirul7200@gmail.com
}

\begin{abstract}
Abstrak
Penelitian ini dilatarbelakangi oleh pembelajaran masih belum optimal karena pembelajaran yang dilakukan guru menonton dan kurang kreatif, sehingga siswa kurang aktif, cepat merasa bosan dan penggunaan media dan sumber belajar yang masih kurang. Data siswa diperoleh siswa yang ikut berpartisipasi aktif dalam pembelajaran hanya ada sebagian siswa saja. Rumusan masalah dalam penelitian ini adalah: apakah model Pembelajaran TPS (Think Pair Share) efektif terhadap sikap belajar siswa pada tema 2, sub tema 1. Sumber Energi Siswa Kelas IV SDN Kutosari Kabupaten Pekalongan?, apakah model Pembelajaran TPS (Think Pair Share) efektif terhadap hasil belajar siswa pada tema 2, sub tema 1. Sumber Energi Siswa Kelas IV SDN Kutosari Kabupaten Pekalongan? Jenis penelitian ini adalah penelitian eksperimen. Rencana penelitian dengan desain rancangan yang digunakan adalah One Group Pre Test and Post Test. Sampel dalam penelitian ini adalah seluruh siswa kelas IV SDN Kutosari Kabupaten Pekalongan. Teknik analisis data menggunakan t-test. Hasil penelitian diperoleh sikap belajar siswa pada kelas pre test diperoleh diperoleh rata-rata sebesar 67 dengan kriteria kurang. Sikap belajar siswa pada kelas post test diperoleh rata-rata sebesar 82 dengan kriteria baik. Hasil perhitungan uji $\mathrm{t}$ diperoleh $\mathrm{t}_{\text {hitung }}=4,225$. Dari daftar distribusi $\mathrm{t}$ dengan $\mathrm{dk}=\mathrm{n}-1=20-1=19$ diperoleh 1,729. Karena 4,225 > 1,729 maka Ho ditolak, sehingga dapat disimpulkan bahwa ada keefektifan Model Pembelajaran TPS (Think Pair Share) terhadap Sikap Belajar dan Hasil Belajar Siswa pada Tema 2, Sub Tema 1. Sumber Energi Siswa Kelas IV SDN Kutosari Kabupaten Pekalongan. Saran yang dapat dihasilkan dalam penelitian ini adalah guru dalam melaksanakan penilaian memperhatikan model pembelajaran Think Pair Share yang digunakan sehingga dapat meningkatkan sikap dan hasil belajar siswa.
\end{abstract}

Kata kunci: Think Pair Share, hasil belajar, sikap belajar siswa.

\begin{abstract}
This research is motivated by learning is still not optimal because the learning done by teachers watching and less creative, so that students are less active, quick to feel bored and the use of media and learning resources are still lacking. Student data obtained by students who actively participated in the learning there are only a few students. The problem formulation in this study is: is the TPS Learning model (Think Pair Share) effective against student learning attitudes on theme 2, sub theme 1. Energy Source of Grade 4 students at SDN Kutosari Pekalongan?, is the TPS Learning Model (Think Pair Share) effective for students' learning outcomes in theme 2, sub-theme 1. Energy Source for Grade 4 students at SDN Kutosari, Pekalongan Regency? This type of research is experimental research. The research plan with the design used is One Group Pre Test and Post Test. The samples in this study were
\end{abstract}


all grade 4 students at SDN Kutosari, Pekalongan Regency. Data analysis techniques using t-test. The results obtained student learning attitude in the pre-test class obtained an average of 67 with less criteria. Students' learning attitudes in post-test classes were obtained by an average of 82 with good criteria. The result of $t$ test calculation obtained thitung $=4,225$. From the distribution list $t$ with $d k=n$ $-1=20-1=19$ obtained 1,729. Because 4,225 > 1,729 then Ho was rejected, so it can be concluded that there is effectiveness of TPS Learning Model (Think Pair Share) on Learning Attitudes and Student Learning Outcomes in Theme 2, Sub Theme 1. Energy Resources for Grade 4 students at SDN Kutosari, Pekalongan Regency. The advice that can be produced in this research is that teachers in carrying out assessments pay attention to the Think Pair Share learning model used so as to improve student attitudes and learning outcomes.

Keywords: Think Pair Share, learning outcomes, student learning attitudes.

\section{PENDAHULUAN}

Pembelajaran dalam Kurikulum 2013 khususnya jenjang sekolah dasar dari kelas 1 sampai dengan kelas 6 menggunakan pendekatan tematik integratif. Mata pelajaran dalam Kurikulum 2013 diintegrasikan menjadi pokok bahasan menggunakan tema dan subtema. Dengan demikian, siswa diharapkan mampu memahami materi secara menyeluruh. Pembelajaran pada sekolah dasar hendaklah memperhatikan berbagai aspek, karena anak pada usia SD memiliki karakteristik tersendiri yang harus dipahami oleh guru. Guru juga harus memahami perkembangan intelektual dan fungsi dari fisik peserta didik. Hal tersebut dimaksudkan agar tidak terjadi permasalahan dalam proses pembelajaran. Menurut Rombepajung dalam Thobroni dan Mustofa (2011: 18) pembelajaran adalah pemerolahan suatu mata pelajaran atau pemerolehan suatu keterampilan melalui pelajaran, pengalaman, atau pengajaran. Pendapat lain dari Kimble dan Garmezy dalam Thobroni dan Mustofa (2011: 18) pembelajaran adalah suatu perubahan perilaku yang relatif tetap dan merupakan hasil praktik yang diulang-ulang. Pendidikan mempunyai peran penting dalam meningkatkan kualitas sumber daya manusia dan upaya mewujudkan cita-cita bangsa Indonesia dalam mewujudkan kesejahteraan umum dan mencerdaskan kehidupan bangsa. Sesuai dengan Undang-undang No. 20 tahun 2003 tentang Sistem pendidikan Nasional, pasal 3 menyebutkan bahwa "Pendidikan Nasional berfungsi mengembangkan kemampuan dan membentuk watak serta peradaban bangsa yang bermartabat rangka mencerdaskan kehidupan bangsa, bertujuan untuk berkembangnya potensi peserta didik agar menjadi manusia yang beriman dan bertakwa kepada Tuhan yang maha Esa, berakhlak mulia, sehat, berilmu, cakap, kreatif, mandiri dan menjadi warga Negara yang demokratis serta bertanggung jawab". Guna mencapai tujuan tersebut makna diperlukan adanya sistem pendidikan dan proses pembelajaran yang baik.

Berdasarkan Kurikulum 2013 adalah kurikulum yang berlaku dalam Sistem Pendidikan di Indonesia. Kurikulum 2013 ini merupakan kurikulum tetap diterapkan oleh pemerintah untuk menggantikan Kurikulum2006 yang biasanya dikenal dengan kurikulum KTSP (Kurikulum Tingkat Satuan Pendidikan), Kurikulum 2013 bertujuan untuk mempersiapkan peserta didik agar memiliki kemampuan hidup sebagai pribadi dan warga negara yang beriman, produktif, kreatif, inovatif, dan 
afektif serta mampu berkontribusi pada kehidupan bermasyarakat, berbangsa, bernegara, dan peradaban dunia.

Berdasarkan hasil observasi pada siswa kelas IV di SDN Kutosari Kabupaten Pekalongan ditemukan bahwa pada pembelajaran tema 2, sub tema 1 sumber energi masih ada siswa yang belum memahami materi. Data hasil belajar ditunjukkan dengan nilai terendah 61 dan nilai tertinggi 86, dengan rata-rata nilai kelas 70,8. Siswa yang mencapai Kriteria Ketuntasan Minial (KKM) sebanyak 30 siswa atau $65 \%$ dari 46 siswa yang mencapai tuntas belajar. Permasalahan pertama pembelajaran masih belum optimal karena pembelajaran yang dilakukan guru menonton dan kurang kreatif, sehingga siswa kurang aktif, cepat merasa bosan dan penggunaan media dan sumber belajar yang masih kurang. Data siswa diperoleh siswa yang ikut berpartisipasi aktif dalam pembelajaran hanya ada sebagian siswa saja. Sikap adalah kecenderungan seseorang untuk menerima atau menolak suatu objek berdasarkan nilai yang dianggapnya baik atau tidak (Sanjaya, 2008: 276). Sikap siswa dalam hal ini terlihat dalam pembelajaran.

Guru dalam memilih model pembelajaran yang tepat untuk meningkatkan hasil belajar siswa. Dalam meningkatkan sikap belajar, maka diadakan suatu penerapan model pembelajaran yang lebih mengutamakan partisipasi aktif siswa dalam kegiatan pembelajaran. Guru sebagai pengajar tidak mendominasi kegiatan, tetapi membantu menciptakan kondisi yang kondusif serta memberikan motivasi dan bimbingan agar siswa dapat meningkatkan hasil belajar.

Pembelajaran dengan model TPS (Think Pair Share) adalah suatu model pembelajaran yang memberi siswa kesempatan untuk bekerja sendiri serta bekerja sama dengan orang lain sehingga terciptanya optimalisasi partisipasi siswa, yaitu memberi kesempatan delapan kali lebih banyak kepada setiap siswa untuk dikenali dan menunjukkan partisipasi mereka kepada orang lain (Isjoni, 2011: 112). Model ini memberi siswa kesempatan untuk bekerja sendiri serta bekerjasama dengan orang lain. Keunggulan dan teknik ini adalah optimalisasi partisipasi siswa, yaitu memberi kesempatan kedelapan kali lebih banyak kepada setiap siswa untuk dikenali dan menunjukkan partisipasi mereka kepada orang lain. Sedangkan peta konsep merupakan suatu cara untuk memperlihatkan konsep-konsep dan proposisi-proposisi suatu bidang studi. Suatu peta konsep merupakan gambar dua dimensi dari suatu bidang studi, atau suatu bagian dari bidang studi (Trianto, 2011: 159). Dengan menggunakan peta konsep diharapkan dapat meningkatkan hasil belajar siswa karena peta konsep merupakan suatu bahan bacaan yang ditentukan oleh guru. Kemudian guru mengurutkan konsep-konsep yang relevan sehingga menjadi suatu bagan yang dapat menjelaskan materi secara rinci.

Penerapan model TPS (Think Pair Share) diawali dengan guru memberikan pertanyaan kepada siswa. Setelah itu siswa berpikir atas jawaban dari pertanyaan guru. Selanjutnya siswa berpasangan. Dengan pasangannya tersebut, siswa berbagi hasil jawabannya kepada pasangannya. Dengan cara ini akan lebih efektif dalam kegiatan pembelajaran sehingga meningkatkan hasil belajar siswa. Sedangkan peta konsep merupakan suatu cara untuk memperlihatkan konsep-konsep dan proposisi-proposisi suatu bidang studi. Suatu peta konsep merupakan gambar dua dimensi dari suatu bidang studi, atau suatu 
bagian dari bidang studi (Trianto, 2011: 159). Peta konsep sebagai evaluasi bertujuan untuk memperjelas pemahaman suatu bacaan, sehingga dapat dipakai sebagai alat evaluasi dengan cara meminta siswa untuk membaca peta konsep dan menjelaskan hubungan antara konsep satu dengan konsep yang lain dalam satu peta konsep.

Penelitian yang dilakukan oleh Tika, Surayya, dan Subagia (2014) menyatakan hasil model pembelajaran Think Pair Share dapat digunakan sebagai alternatif model pembelajaran untuk meningkatkan hasil belajar IPA. Pembelajaran kooperatif Think Pair Share (TPS) dipadu peta konsep efektif untuk meningkatkan motivasi dan hasil belajar siswa kelas XI IPA SMA Negeri 10 Malang.

Penelitian yang telah dilakukan oleh Eva Nuraisah (2015) yang menyatakan bahwa ada perbedaan pengaruh penggunaan pembelajaran konvensional dan pendekatan kontekstual terhadap kemampuan berpikir kritis matematis dan motivasi belajar siswa pada materi pecahan.

Temuan hasil penelitian yang relevan di atas, dapat disimpulkan bahwa pembelajaran dengan model pembelajaran Think Pair Share (TPS) dan konvensional memiliki efek berbeda terhadap untuk meningkatkan motivasi, berpikir kritis dan hasil belajar siswa sehingga dapat dijadikan sebagai acuan dalam penelitian ini.

Dari ulasan latar belakang tersebut di atas maka peneliti mengkaji melalui penelitian dengan judul "Keefektifan Model Pembelajaran TPS (Think Pair Share) terhadap Sikap Belajar dan Hasil Belajar Siswa pada Tema 2, Sub Tema 1. Sumber Energi Siswa Kelas IV SDN Kutosari Kabupaten Pekalongan".

\section{METODE PENELITIAN}

Jenis penelitian ini adalah penelitian eksperimen. Rencana penelitian dengan desain rancangan yang digunakan adalah One Group Pre Test and Post Test. Sampel dalam penelitian ini adalah seluruh siswa kelas IV SDN Kutosari Kabupaten Pekalongan. Teknik analisis data menggunakan t-test.

\section{HASIL DAN PEMBAHASAN}

Penelitian ini bertujuan untuk mengetahui keefektifan Model Pembelajaran TPS (Think Pair Share) terhadap Sikap Belajar dan Hasil Belajar Siswa pada Tema 2, Sub Tema 1. Sumber Energi Siswa Kelas IV SDN Kutosari Kabupaten Pekalongan. Penelitian ini bertujuan untuk mengetahui keefektifan Model Pembelajaran TPS (Think Pair Share) terhadap Sikap Belajar dan Hasil Belajar Siswa pada Tema 2, Sub Tema 1. Sumber Energi Siswa Kelas IV SDN Kutosari Kabupaten Pekalongan. Berdasarkan nilai pre test diperoleh rata-rata nilai 79,6 dengan nilai tengah 80 dan modus 80. Dari nilai ketuntasan, diperoleh KKM dari SDN Kutosari Kabupaten Pekalongan pada tema 2, sub tema 1. sumber energi diperoleh nilai 76. Hasil data siswa yang mengalami ketuntasan belajar terdapat 15 siswa dan 5 siswa yang tidak tuntas belajar. 
Nilai post test diperoleh diperoleh rata-rata nilai 87,400 dengan nilai tengah 90 dan modus 90. Dari nilai ketuntasan, diperoleh KKM dari SDN Kutosari Kabupaten Pekalongan pada tema 2, sub tema 1. sumber energi siswa adalah 76. Hasil data siswa yang mengalami ketuntasan belajar terdapat 18, dan 2 siswa yang tidak tuntas belajar. Pada nilai pre test dengan nilai rata- rata hasil belajar sebesar 79,600. Sedangkan pada nilai post test dengan nilai rata - rata hasil belajar sebesar 87,400. Peningkatan nilai kognitif siswa ini sesuai dengan pendapat Bloom (2017) perilaku-perilaku yang menekankan aspek intelektual, seperti pengetahuan, pengertian, dan keterampilan berpikir. Pengetahuan yang berupa hasil belajar siswa pada tema 2 , sub tema 1 . sumber energi siswa.

Berdasarkan hasil perhitungan uji $\mathrm{t}$ diperoleh $\mathrm{t}_{\text {hitung }}=4,225$. Dari daftar distribusi $\mathrm{t}$ dengan $\mathrm{dk}=$ $\mathrm{n}-1=20-1=19$ diperoleh 1,729. Karena 4,225>1,729 maka Ho ditolak, sehingga dapat disimpulkan bahwa . ada keefektifan Model Pembelajaran TPS (Think Pair Share) terhadap Sikap Belajar dan Hasil Belajar Siswa pada Tema 2, Sub Tema 1. Sumber Energi Siswa Kelas IV SDN Kutosari Kabupaten Pekalongan. Penerapan model pembelajaran ini dapat meningkatkan hasil belajar siswa. Hal ini dikarenakan model pembelajaran Think Pair Share yang memiliki kelebihan yaitu suatu model pembelajaran yang berusaha meletakkan dasar dan mengembangkan cara berpikir ilmiah, yang menempatkan siswa lebih banyak belajar sendiri, mengembangkan kekreatifan dalam memecahkan masalah. Siswa mempelajari materi pelajaran secara kelompok dan menghubungkannya dengan kegiatan yang berlangsung. Disini guru hanya berperan sebagai fasilitator. Meningkatkan sikap belajar siswa, menambah kepercayaan diri dalam diri siswa.

Pembelajaran dengan model Think Pair Share ini mengajarkan siswa untuk dapat mandiri dan percaya diri dalam pengembangan dirinya sebagai manusia yang mempunyai sifat ingin tahu, aktif, kreatif, guru mampu meningkatkan sifat tersebut yang dihubungkan dengan permasalahan yang sering dihadapi oleh siswa, sehingga siswa memiliki kemauan untuk melakukan percobaan atau pengamatan untuk mengetahui jawabannya. Model Think Pair Share ini juga menciptakan suasana yang menyenangkan, sehingga sebagian besar siswa aktif selama proses pembelajaran.

Dengan penerapan model pembelajaran Think Pair Share kegiatan pembelajaran lebih menarik dan menyenangkan. Hal ini membuat siswa lebih aktif untuk belajar, aktif berfikir dan menyampaikan pendapatnya sehingga situasi kelas lebih hidup, siswa dapat terlatih dalam mengemukakan pandapat dengan lisan secara teratur, karena setiap siswa memiliki perbedaan pendapat sehingga membawa kelas pada situasi diskusi kelompok yang menarik, siswa biasanya segan mencurahkan perhatian namun dengan adanya diskusi kelompok siswa menjadi lebih sungguh-sungguh mengikuti pelajaran sehingga hasil belajar siswa menjadi optimal.

Pembelajaran dengan model pembelajaran Think Pair Share adalah kegiatan pembelajaran dimana guru menggunakan guru membagi siswa menjadi beberapa kelompok masing-masing kelompok mendapatkan nomor untuk dipakai di kepala dan memberikan masing-masing kelompok lembar kerja siswa. Guru meminta siswa melakuan praktikum di luar kelas. Seelah kegiatan praktikum selesai, siswa kembali ke kelas dan ke kelompknya masing-masing. Guru mengajukan suatu pertanyaan atau masalah 
yang dikaitkan dengan pembelajaran, dan meminta siswa untuk menggunakan waktu untuk mencari jawaban. Setelah itu guru meminta siswa untuk mendiskusikan apa yang telah siswa peroleh. Guru memberikan waktu kepada siswa untuk menyatukan gagasan yang telah teridentifikasi. Guru memberikan waktu kepada siswa lima menit untuk berpasangan. Pada langkah akhir, guru meminta masing-masing perwakilan dari kelompok untuk mempresentasikan di depan kelas.

Sedangkan pembelajaran dengan metode ceramah, guru memberikan ceramah kepada siswa dan siswa relatif pasif dan kurang aktif dalam mengikuti pembelajaran karena hanya mendengarkan penjelasan dari guru. Dalam pembelajaran ini guru menyajikan materi di depan kelas secara klasikal yang difokuskan pada konsep-konsep dari materi yang akan dibahas. Dengan metode ceramah, guru yang aktif untuk memberikan penjelasan tanpa adanya interaksi dengan siswa. Hal ini mengakibatkan siswa cenderung bosan sehingga mempengaruhi hasil belajar.

Faktor guru sangat mendukung berjalanya proses belajar mengajar. Guru hendaknya dapat menggunakan metode yang bervariasi dalam proses pembelajaran sehingga siswa akan lebih tertarik dan termotivasi untuk mengikuti pelajaran. Penelitian ini guru mengunakan dua model yang berbeda yaitu dengan model Think Pair Share dan model konvensional dengan ceramah. Guru juga harus berusaha menyediakan lingkungan belajar yang kreatif dan kondusif dengan tujuan untuk membangkitkan aktivitas siswa. Penerapan model pembelajaran Think Pair Share lebih meningkatkan aktivitas belajar siswa karena siswa dilatih untuk berpikir secara logis dan dapat meningkatkan kemampuan berpikir dalam memecahkan suatu masalah, dan siswa yang pasif dapat dirangsang secara aktif oleh anggota kelompok lain. Sikap siswa dalam kelompok juga diharapkan akan membuat siswa lebih tertarik atau berminat dalam belajar, karena penanaman dan pengembangan konsep nilai dan moral dapat dicapai bila mana siswa secara langsung berinteraksi satu sama lainnya dalam pemecahan masalah. Oleh karena itu dengan adanya diskusi ini dapat memberikan pengalaman dan keterampilan dalam mengemukakan keinginan yang ada dalam diri siswa.

Perbedaan tersebut terlihat pada saat terjadinya proses belajar di kelas post test yang terpacu sikap siswa karena siswa melakukan kegiatan mengidentifikasi gambar sehingga lebih aktif dalam mengikuti pembelajaran. Siswa berbagi dengan kelompok lain. Sementara kelas pre test, siswa relatif pasif dan kurang aktif dalam mengikuti pembelajaran karena materi disampaikan secara konvensional. Pembelajaran dengan model Think Pair Share ini ini mengajarkan siswa untuk dapat mandiri dan percaya diri dalam pengembangan dirinya sebagai manusia yang mempunyai sifat ingin tahu, aktif, kreatif, guru mampu meningkatkan sifat tersebut yang dihubungkan dengan permasalahan yang sering dihadapi oleh siswa, sehingga siswa memiliki kemauan untuk melakukan percobaan atau pengamatan untuk mengetahui jawabannya. Model Think Pair Share ini juga menciptakan suasana yang menyenangkan, sehingga sebagian besar siswa aktif selama proses pembelajaran. Dengan penerapan model pembelajaran Think Pair Share kegiatan pembelajaran lebih menarik dan menyenangkan. Hal ini membuat siswa lebih aktif untuk belajar, aktif berfikir dan menyampaikan pendapatnya sehingga situasi kelas lebih hidup, siswa dapat terlatih dalam mengemukakan pandapat dengan lisan secara teratur, 
karena setiap siswa memiliki perbedaan pendapat sehingga membawa kelas pada situasi diskusi kelompok yang menarik, siswa biasanya segan mencurahkan perhatian namun dengan adanya diskusi kelompok siswa menjadi lebih sungguh-sungguh mengikuti pelajaran sehingga hasil belajar siswa menjadi optimal.

Berdasarkan hasil analisa dan pengamatan terhadap sikap siswa, siswa terlibat secara aktif dalam pembelajaran yang menggunakan Think Pair Share. Hal ini dilihat dari sikap siswa di dalam kegiatan kelompok, diskusi, berpikir. Dengan demikian penelitian ini menunjukan bahwa pengajaran dengan model pembelajaran Think Pair Share memberikan hasil yang lebih baik dibandingkan dengan pengajaran Tema 2 secara konvensional.

\section{PENUTUP}

\section{SIMPULAN}

Berdasarkan hasil penelitian dapat disimpulkan bahwa:

1. Sikap belajar siswa pada kelas pre test diperoleh diperoleh rata-rata sebesar 67 dengan kriteria kurang. Sikap belajar siswa pada kelas post test diperoleh rata-rata sebesar 82 dengan kriteria baik.

2. Hasil perhitungan uji $\mathrm{t}$ diperoleh $\mathrm{t}_{\text {hitung }}=4,225$. Dari daftar distribusi $\mathrm{t}$ dengan $\mathrm{dk}=\mathrm{n}-1=20-1=$ 19 diperoleh 1,729. Karena 4,225 > 1,729 maka Ho ditolak, sehingga dapat disimpulkan bahwa ada keefektifan Model Pembelajaran TPS (Think Pair and Share) terhadap Sikap Belajar dan Hasil Belajar Siswa pada Tema 2, Sub Tema 1. Sumber Energi Siswa Kelas IV SDN Kutosari Kabupaten Pekalongan.

\section{SARAN}

Guru dalam melaksanakan penilaian memperhatikan model pembelajaran Think Pair Share yang digunakan sehingga dapat meningkatkan sikap dan hasil belajar siswa.

\section{DAFTAR PUSTAKA}

Agus Suprijono. 2006. Cooperative Learning. Yogyakarta : Pustaka Belajar.

Anita Lie. 2004. Cooperative Learning. Jakarta: Grasindo.

Arikunto, S. 2002. Prosedur Penelitian Suatu Pendekatan Praktek. Jakarta: PT Rineka Cipta.

Arikunto, S. 2006. Prosedur Penelitian Suatu Pendekatan Praktek. Jakarta: PT Rineka Cipta.

Dimyati dan Mujiono. 2009. Belajar dan pembelajaran. Jakarta: Rineka Cipta.

Djamarah, Syaiful Bahri dan Aswan Zain. 2006. Strategi Belajar Mengajar. Jakarta: Rineka Cipta.

Depdiknas. 2006. Peningkatan Kualitas Pembelajaran. Jakarta: Depdiknas.

Dimyati dan Mudjiono. 2009. Belajar dan Pembelajaran. Jakarta: PT Rineka Cipta. 
Djamarah, Syaiful Bahri. 2008. Psikologi Belajar. Jakarta: PT Rineka Cipta.

Ghufron, M. Nur dan Rinsawati, Rini. 2010. Teori-teori Psikologi. Jogjakarta: Ar-Ruzz Media.

Hamalik, Oemar. 2009. Psikologi Belajar dan Mengajar. Bandung: Sinar Baru Algensindo.

Hamdani. 2010. Strategi Belajar Mengajar. Bandung: Pustaka Setia.

Huda, Miftahul. 2015. Cooperative Learning, Metode, Teknik, Struktur dan Model Penerapan. Yogyakarta: Pustaka Pelajar.

Isjoni. 2011. Pembelajaran Kooperatif Meningkatkan Kecerdasan Komunikasi Antar Peserta Didik. Yogyakarta: Pustaka Pelajar.

Rusman. 2012. Model-model Pembelajaran Mengembangkan Profesionalisme Guru. Jakarta: PT. Raja Grafindo Persada.

Sanjaya, Wina. 2008. Strategi Pembelajaran Berorientasi Standar Proses Pendidikan. Jakarta: Prenada Media.

Syah, Muhibbin. 2009. Psikologi Belajar. Jakarta: Rajawali Press.

Sardiman. 2005. Interaksi dan Motivasi Belajar. Jakarta: PT. Raja Grafindo.

Sudjana, N., 2009. Dasar-dasar Proses Belajar Mengajar. Bandung : Penerbit Sinar Baru Algesindo.

Suharso dan Retnaningsih. 2011. Kamus Besar Bahasa Indonesia. Jakarta: Rineka Cipta.

Sudjana. 2005. Matode Statistika. Bandung: Tarsito.

Sugiyono. 2006. Statistik Non Parametris untuk Penelitian. Bandung: CV. Alfabeta.

Trianto. 2011. Model-model Pembelajaran Inovatif Berorientasi Konstruktivistik. Surabaya: Prestasi Pustaka Publisher. 